\title{
Development of Standards for Hydrogen Storage and Transportation
}

\author{
Yanmei Yang ${ }^{1, *}$, Haigang X $u^{2}$, Qiaoling $\mathrm{Lu}^{1}$, Wei Bao ${ }^{1,3}$, Ling Lin $^{1}$, Bin Ai ${ }^{3}$, Bangqiang Zhang ${ }^{3}$ \\ ${ }^{1}$ China National Institute of Standardization, 100191 Beijing, China \\ ${ }^{2}$ Shanghai Institute of Space Propulsion, 201112 Shanghai, China \\ ${ }^{3}$ Foshan Green Development Innovation Research Institute, 528200 Guangdong, China
}

\begin{abstract}
Hydrogen storage and transportation are the intermediate link of hydrogen production and the point of end-use. Standards for hydrogen storage and transportation published by ISO, CGA, NFPA, ASME, ANSI, SAC, CEN and JISC are reviewed and analysed in this paper. Numbers of standards for hydrogen embrittlement are more than the others. Standards for hydrogen piping and pipelines are only published by CGA and ASME. Chinese GB standards are mainly focused on general design and safety, gaseous hydrogen receptacles and hydrogen embrittlement. Standards for liquid hydrogen storage receptacles and safety, hydrogen piping and pipelines, and hydrogen transportation should be emphasized.
\end{abstract}

\section{Introduction}

Hydrogen industry is booming in recent years under the propulsion of development of technology, climate change and energy revolution. Hydrogen can be produced from coals, natural gas, industry by-products, water, etc. The production site is always far away from the point of enduse. Hydrogen storage and transportation is the intermediate link of hydrogen production and the point of end-use. Infrastructure of hydrogen storage and transportation includes tube trailers, pipelines, and storage facilities involved in the process of delivering hydrogen, etc. $[1,2]$

Hydrogen can be transported in different states, including gaseous hydrogen, liquid hydrogen and hydrogen carriers, etc. Gaseous hydrogen is the most commonly transported by tube trailers. When high volume hydrogen transportation is needed, it is often transported as the liquid. Hydrogen carriers store hydrogen in some other chemicals rather than as free hydrogen molecules, including liquid and solid hydrogen carriers.

In this paper, standards for hydrogen storage and transportation published by International Organization for Standardization (ISO), American National Standards Institute (ANSI), Compressed Gas Association (CGA), National Fire Protection Association (NFPA), American Society of Mechanical Engineers (ASME), European Committee for Standardization (CEN), State Standardization Administration of the P.R.C. (SAC), Japanese Industrial Standards Committee (JISC) are reviewed and analyzed. Suggestions of standards for hydrogen storage and transportation for China are proposed.

\section{Standardization organizations}

\subsection{ISO}

Technical Committee of Hydrogen Technologies (ISO/TC 197) is specialized in standardization in the field of systems and devices for the production, storage, transport, measurement and use of hydrogen [3]. Technical Committee of Surface coatings (ISO/TC 2/SC 4), Methods of testing (ISO/TC 17/SC 7), Copper and copper alloys (ISO/TC 26), Gas cylinders (ISO/TC 58), and Corrosion of metals and alloys (ISO/TC 156) are specialized in preparing standards for hydrogen embrittlement.

\subsection{American organizations}

American National Standards Institute (ANSI), Compressed Gas Association (CGA), National Fire Protection Association (NFPA), American Society of Mechanical Engineers (ASME) are all specialized in preparing standards for hydrogen storage and transportation [4-7].

\subsection{CEN}

European Committee for Standardization (CEN) is a public organization which prepares European Standards (EN standards) and other technical documents in relation to various kinds of products, materials, services and processes [8]. CEN/TC 23 (Transportable gas cylinders) covers standardization of transportable gas cylinders, their fittings, and requirements relating to their design,

\footnotetext{
* Corresponding author: yangym@cnis.ac.cn
} 
testing and operation. CEN/TC 133 (Copper and copper alloys), CEN/TC 185 (Fasteners), CEN/TC 262 (Metallic and other inorganic coatings, including for corrosion protection and corrosion testing of metals and alloys), and CEN/TC 459/SC 1 (Test methods for steel (other than chemical analysis)) are technical bodies which prepare standards for hydrogen embrittlement.

\subsection{SAC}

Standardization Administration of the People's Republic of China (SAC) supervises and coordinates standardization work in China. Technical Committee of Hydrogen Energy (SAC/TC 309), High Pressure Vehicle Fuel Tanks (SAC/TC 31/SC 8), Road Vehicles (SAC/TC 114), and Boilers and Pressure Vessels (SAC/TC 262) are the main technical committees which devote to develop standards for hydrogen storage and transportation. Technical Committee of Nonferrous Metals (SAC/TC 243), Metallic and Non-metallic Coatings (SAC/TC 57), Steel (SAC/TC 183) and Fasteners (SAC/TC 85) prepare standards for hydrogen embrittlement. SAC published Chinese national standards are marked as GB standards [9].

\subsection{JISC}

The Japanese Industrial Standards Committee (JISC), Japan's national standardization body, plays a central role in developing standards in Japan covering a wide range of products and technologies [10]. JISC published standards are marked as JIS standards .

\section{Standards for hydrogen storage and transportation}

As is shown in Figure 1, standards for hydrogen storage and transportation include general design and safety, receptacles, piping and pipelines, hydrogen embrittlement, etc.

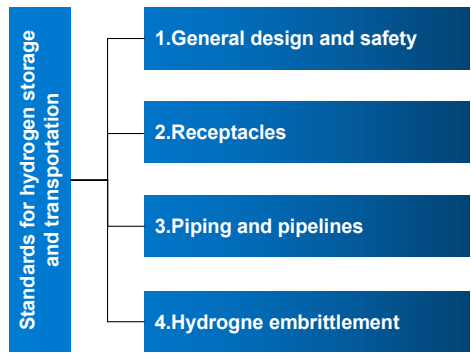

Fig. 1. Framework of Standards for Hydrogen Storage and Transportation

\subsection{General design and safety}

As is listed in Table 1, there are 14 standards for general design and safety, including 8 CGA standards, 2 NFPA standards and 4 GB standards. CGA standards cover the installation, handling, safety and set of hydrogen storage and supply systems. NFPA 2 covers fundamental requirements of storage and piping of compressed gaseous hydrogen and cryogenic liquid hydrogen. NPFA 55 covers the storage requirements of compressed gases and cryogenic hydrogen in portable and stationary containers, cylinders and tanks. GB standards provide safety requirements for hydrogen transportation, hydrogen storage devices and systems.

Table 1. General design and safety standards for hydrogen storage and transportation $[5,6,9]$

\begin{tabular}{|c|c|c|}
\hline No. & $\begin{array}{l}\text { Number of } \\
\text { standards }\end{array}$ & Name of standards \\
\hline 1 & CGA H-5-2014 & $\begin{array}{l}\text { Installation standard for bulk } \\
\text { hydrogen supply systems }\end{array}$ \\
\hline 2 & CGA P-12-2017 & $\begin{array}{l}\text { Safe handling of cryogenic } \\
\text { liquids }\end{array}$ \\
\hline 3 & CGA PS-17-2004 & $\begin{array}{l}\text { CGA position statement on } \\
\text { underground installation of } \\
\text { liquid hydrogen storage tanks }\end{array}$ \\
\hline 4 & CGA PS-20 & $\begin{array}{l}\text { CGA Position statement on the } \\
\text { direct burial of gaseous } \\
\text { hydrogen storage tanks }\end{array}$ \\
\hline 5 & CGA P-28-2014 & $\begin{array}{l}\text { Risk management plan } \\
\text { guidance document for bulk } \\
\text { liquid hydrogen systems }\end{array}$ \\
\hline 6 & CGA P-41-2018 & $\begin{array}{l}\text { Locating bulk liquid storage } \\
\text { systems in courts }\end{array}$ \\
\hline 7 & CGA PS-46-2017 & $\begin{array}{l}\text { Position statement - roofs over } \\
\text { hydrogen storage systems }\end{array}$ \\
\hline 8 & CGA PS-48-2016 & $\begin{array}{l}\text { CGA Position statement on } \\
\text { clarification of existing } \\
\text { hydrogen setback distances and } \\
\text { development of new hydrogen } \\
\text { setback distances in NFPA 55 }\end{array}$ \\
\hline 9 & NFPA 2 & Hydrogen technologies code \\
\hline 10 & NFPA 55 & $\begin{array}{l}\text { Compressed gases and } \\
\text { cryogenic fluids code }\end{array}$ \\
\hline 11 & GB/T 34583-2017 & $\begin{array}{l}\text { Safety technical requirements } \\
\text { for hydrogen storage devices } \\
\text { used in hydrogen fuelling } \\
\text { station }\end{array}$ \\
\hline 12 & GB/T 34584-2017 & $\begin{array}{l}\text { Safety technical regulations for } \\
\text { hydrogen refueling station }\end{array}$ \\
\hline 13 & GB/T 29729-2013 & $\begin{array}{l}\text { Essential requirements for the } \\
\text { safety of hydrogen systems }\end{array}$ \\
\hline 14 & $\begin{array}{l}\text { GB/T 34542.1- } \\
2017\end{array}$ & $\begin{array}{l}\text { Storage and transportation } \\
\text { systems for gaseous hydrogen- } \\
\text { Part 1: General requirements }\end{array}$ \\
\hline
\end{tabular}

\subsection{Receptacles}

Hydrogen receptacles include cylinders, tanks, storage devices, containers, storage buffers, etc. As is shown in Table 2, Table 3 and Table 4, there are 22 standards for hydrogen receptacles.

Table 2 shows standards for stationary and transportable receptacles, including 1 ISO standard, 2 GB standards, 2 CGA standards and 2 EN standards. ISO 16111:2018 and GB/T 33292-2016 are standards for metal hydride hydrogen storage devices and systems. GB/T 26466-2011, EN 17533: 2020, EN 17339: 2020 and CGA PS-33-2008 (R2014) are standards for gas hydrogen stationary storage. 
CGA H-3-2019 is the standard for cryogenic hydrogen Storage.

Table 2. Standards for stationary and transportable hydrogen storage receptacles[3,5,8,9]

\begin{tabular}{|c|l|l|}
\hline No. & \multicolumn{1}{|c|}{$\begin{array}{c}\text { Number of } \\
\text { standards }\end{array}$} & \multicolumn{1}{|c|}{ Name of standards } \\
\hline 1 & ISO 16111:2018 & $\begin{array}{l}\text { Transportable gas storage } \\
\text { devices - Hydrogen absorbed } \\
\text { in reversible metal hydride }\end{array}$ \\
\hline 2 & GB/T 26466-2011 & $\begin{array}{l}\text { Stationary flat steel ribbon } \\
\text { wound vessels for storage of } \\
\text { high pressure hydrogen }\end{array}$ \\
\hline 3 & GB/T 33292-2016 & $\begin{array}{l}\text { Metal hydride hydrogen } \\
\text { storage system for fuel cells } \\
\text { backup power }\end{array}$ \\
\hline 4 & CGA H-3-2019 & $\begin{array}{l}\text { Standard for cryogenic } \\
\text { Hydrogen Storage }\end{array}$ \\
\hline 5 & $\begin{array}{l}\text { CGA PS-33-2008 } \\
\text { R2014) }\end{array}$ & $\begin{array}{l}\text { Use of liquefied petroleum gas } \\
\text { or propane tanks as } \\
\text { compressed hydrogen storage } \\
\text { buffers }\end{array}$ \\
\hline 6 & EN 17533: 2020 & $\begin{array}{l}\text { Gaseous hydrogen - Cylinders } \\
\text { and tubes for stationary storage }\end{array}$ \\
\hline EN 17339: 2020 & $\begin{array}{l}\text { Transportable gas cylinders - } \\
\text { Fully wrapped carbon } \\
\text { composite cylinders and tubes } \\
\text { for hydrogen }\end{array}$ \\
\hline
\end{tabular}

Table 3 shows standards for hydrogen receptacles of fuel cell vehicles, including 3 ISO standards, 4 GB standards and 2 ANSI standards. ISO 13985:2006 specifies the requirements of liquid hydrogen storage tanks on land vehicles. ISO 19881:2018, GB/T 34544-2017, GB/T 29126-2012, GB/T 26990-2011, GB/T 35544-2017 and ANSI HGV 2-2014 are for gaseous hydrogen land vehicle fuel containers and systems. ISO 19882:2018 and ANSI/CSA HPRD1-2013 are standard for thermally activated pressure relief devices for compressed hydrogen vehicle fuel containers.

Table 3. Standards for hydrogen receptacles of fuel cell vehicles[3,4,9]

\begin{tabular}{|c|l|l|}
\hline No. & \multicolumn{1}{|c|}{$\begin{array}{c}\text { Number of } \\
\text { standards }\end{array}$} & \multicolumn{1}{c|}{ Name of standards } \\
\hline 1 & ISO 13985:2006 & $\begin{array}{l}\text { Liquid hydrogen - Land vehicle } \\
\text { fuel tanks }\end{array}$ \\
\hline 2 & ISO 19881:2018 & $\begin{array}{l}\text { Gaseous hydrogen - Land vehicle } \\
\text { fuel containers }\end{array}$ \\
\hline 3 & ISO 19882:2018 & $\begin{array}{l}\text { Gaseous hydrogen - Thermally } \\
\text { activated pressure relief devices } \\
\text { for compressed hydrogen vehicle } \\
\text { fuel containers }\end{array}$ \\
\hline 4 & $\begin{array}{l}\text { GB/T } 34544- \\
2017\end{array}$ & $\begin{array}{l}\text { Safety test methods for onboard } \\
\text { low pressure hydrogen storage } \\
\text { devices for small fuel cell } \\
\text { vehicles }\end{array}$ \\
\hline 6 & $\begin{array}{l}\text { GB/T } 2012 \\
2011\end{array}$ & $\begin{array}{l}\text { Fuel cell electric vehicles - } \\
\text { Onboard hydrogen system - Test } \\
\text { methods }\end{array}$ \\
\hline 7 & $\begin{array}{l}\text { GB/T } 26990- \\
2017\end{array}$ & $\begin{array}{l}\text { Fuel cell electric vehicles - } \\
\text { Onboard hydrogen system - } \\
\text { Specifications }\end{array}$ \\
\hline
\end{tabular}

\begin{tabular}{|c|l|l|}
\hline & & $\begin{array}{l}\text { aluminum liner for the on-board } \\
\text { storage of compressed hydrogen } \\
\text { as a fuel for land vehicles }\end{array}$ \\
\hline 8 & $\begin{array}{l}\text { ANSI/CSA } \\
\text { HPRD1-2013 }\end{array}$ & $\begin{array}{l}\text { Standard for thermally activated } \\
\text { pressure relief devices for } \\
\text { compressed hydrogen vehicle } \\
\text { fuel containers }\end{array}$ \\
\hline 9 & $\begin{array}{l}\text { ANSI HGV 2- } \\
\text { Compressed hydrogen gas } \\
\text { vehicle fuel containers }\end{array}$ \\
\hline
\end{tabular}

Table 4 shows standards for hydrogen storage materials, including 1 GB standard and 5 JIS standards. GB and JIS standards are all for hydrogen absorbing materials.

Table 4. Standards for hydrogen storage materials $[9,10]$

\begin{tabular}{|c|l|l|}
\hline No. & \multicolumn{1}{|c|}{$\begin{array}{c}\text { Number of } \\
\text { standards }\end{array}$} & \multicolumn{1}{|c|}{ Name of standards } \\
\hline 1 & GB/T 33291-2016 & $\begin{array}{l}\text { Measurement method of } \\
\text { pressure-composition- } \\
\text { temperature for reversible } \\
\text { hydrogen absorption \& } \\
\text { desorption of hydrides }\end{array}$ \\
\hline 2 & JIS H 7003:2007 & $\begin{array}{l}\text { Glossary of terms used in } \\
\text { hydrogen absorbing alloys }\end{array}$ \\
\hline 3 & JIS H 7201:2007 & $\begin{array}{l}\text { Method for measurement of } \\
\text { pressure-composition- } \\
\text { temperature(PCT) relations of } \\
\text { hydrogen absorbing alloys }\end{array}$ \\
\hline 4 & JIS H 7202:2007 & $\begin{array}{l}\text { Method for measurement of } \\
\text { hydrogen } \\
\text { absorption/desorption reaction } \\
\text { rate of hydrogen absorbing } \\
\text { alloys }\end{array}$ \\
\hline 5 & JIS H 7203:2007 & $\begin{array}{l}\text { Method for measurement of } \\
\text { hydrogen } \\
\text { absorption/desorption cycle } \\
\text { characteristic of hydrogen } \\
\text { absorbing alloys }\end{array}$ \\
\hline JIS H 7204:1995 & $\begin{array}{l}\text { Method for measuring the heat } \\
\text { of hydrating reaction of } \\
\text { hydrogen absorbing alloys }\end{array}$ \\
\hline
\end{tabular}

\subsection{Piping and pipelines}

Standards for hydrogen piping and pipelines are shown in Table 5, including 3 CGA standards and 2 ASME standards.

Table 5. Standards for hydrogen piping and pipelines $[5,7]$

\begin{tabular}{|c|l|l|}
\hline No. & \multicolumn{1}{|c|}{$\begin{array}{c}\text { Number of } \\
\text { standards }\end{array}$} & \multicolumn{1}{|c|}{ Name of standards } \\
\hline 1 & CGA G-5.4-2019 & $\begin{array}{l}\text { Standard for hydrogen piping } \\
\text { systems at user locations }\end{array}$ \\
\hline 2 & CGA G-5.6-2005 & Hydrogen pipeline systems \\
\hline 3 & CGA G-5.8-2007 & $\begin{array}{l}\text { High pressure hydrogen piping } \\
\text { systems at consumer locations }\end{array}$ \\
\hline 4 & $\begin{array}{l}\text { ASME B31.12- } \\
2019\end{array}$ & Hydrogen piping and pipelines \\
\hline 5 & $\begin{array}{l}\text { ASME STP-PT- } \\
006-2017\end{array}$ & $\begin{array}{l}\text { Design guidelines for hydrogen } \\
\text { piping and pipelines }\end{array}$ \\
\hline
\end{tabular}

\subsection{Hydrogen embrittlement}


Hydrogen embrittlement standards are shown in Table 6, including 9 ISO standards, 9 GB standards, 1 ANSI standard, 8 EN standards and 2 JIS standards. ISO 9587:2007, ISO 9588:2007, GB/T 13322-1991, GB/T 19349-2012 and GB/T 19350-2012 are standards for hydrogen embrittlement protection. The other standards for hydrogen embrittlement testing.

Table 6. Standards for hydrogen embrittlement[3,4,8-10]

\begin{tabular}{|c|c|c|}
\hline No. & $\begin{array}{l}\text { Number of } \\
\text { standards }\end{array}$ & Name of standards \\
\hline 1 & ISO 2626:1973 & $\begin{array}{lll}\text { Copper }- & \text { Hydrogen } \\
\text { embrittlement test } & \end{array}$ \\
\hline 2 & $\begin{array}{l}\text { ISO/TR } \\
\text { 20491:2019 }\end{array}$ & $\begin{array}{l}\text { Fasteners - Fundamentals of } \\
\text { hydrogen embrittlement in } \\
\text { steel fasteners }\end{array}$ \\
\hline 3 & ISO 15330:1999 & $\begin{array}{l}\text { Fasteners - Preloading test for } \\
\text { the detection of hydrogen } \\
\text { embrittlement - parallel } \\
\text { bearing surface method }\end{array}$ \\
\hline 4 & ISO 16573:2015 & $\begin{array}{l}\text { Steel - Measurement method } \\
\text { for the evaluation of hydrogen } \\
\text { embrittlement resistance of } \\
\text { high strength steels }\end{array}$ \\
\hline 5 & ISO 9587:2007 & $\begin{array}{l}\text { Metallic and other inorganic } \\
\text { coatings - Pretreatment of iron } \\
\text { or steel to reduce the risk of } \\
\text { hydrogen embrittlement }\end{array}$ \\
\hline 6 & ISO 9588:2007 & $\begin{array}{l}\text { Metallic and other inorganic } \\
\text { coatings - Post-coating } \\
\text { treatments of iron or steel to } \\
\text { reduce the risk of hydrogen } \\
\text { embrittlement }\end{array}$ \\
\hline 7 & ISO 7539-11:2013 & $\begin{array}{l}\text { Corrosion of metals and alloys } \\
\text { - Stress corrosion testing - Part } \\
\text { 11: Guidelines for testing the } \\
\text { resistance of metals and alloys } \\
\text { to hydrogen embrittlement and } \\
\text { hydrogen-assisted cracking }\end{array}$ \\
\hline 8 & ISO 10587:2000 & $\begin{array}{l}\text { Metallic and other inorganic } \\
\text { coatings - Test for residual } \\
\text { embrittlement in both metallic- } \\
\text { coated and uncoated } \\
\text { externally-threaded articles } \\
\text { and rods - Inclined wedge } \\
\text { method }\end{array}$ \\
\hline 9 & ISO 11114-4:2017 & $\begin{array}{l}\text { Transportable gas cylinders - } \\
\text { Compatibility of cylinder and } \\
\text { valve materials with gas } \\
\text { contents - Part 4: Test methods } \\
\text { for selecting steels resistant to } \\
\text { hydrogen embrittlement }\end{array}$ \\
\hline 10 & $\begin{array}{l}\text { GB/T 34542.2- } \\
2018\end{array}$ & $\begin{array}{l}\text { Storage and transportation } \\
\text { systems for gaseous hydrogen- } \\
\text { Part 2: Test methods for } \\
\text { evaluating metallic material } \\
\text { compatibility in hydrogen } \\
\text { atmosphere }\end{array}$ \\
\hline 11 & $\begin{array}{l}\text { GB/T 34542.3- } \\
2018\end{array}$ & $\begin{array}{l}\text { Storage and transportation } \\
\text { systems for gaseous hydrogen- } \\
\text { Part 3: Test method for } \\
\text { determination of the } \\
\text { susceptibility of metallic } \\
\text { materials to hydrogen gas } \\
\text { embrittlement (HGE) }\end{array}$ \\
\hline
\end{tabular}

\begin{tabular}{|c|c|c|}
\hline 12 & GB/T 23606-2009 & $\begin{array}{lll}\text { Copper-hydrogen } & & \\
\text { embrittlement } & \text { test } \\
\text { method(MOD } \quad: & \text { ISO } \\
2626: 1973) & & \\
\end{array}$ \\
\hline 13 & GB/T 13322-1991 & $\begin{array}{l}\text { Metallic } \\
\text { plating of low hydrogeng-Cd-Ti } \\
\text { embrittlement }\end{array}$ \\
\hline 14 & GB/T 19349-2012 & $\begin{array}{l}\text { Metallic and other inorganic } \\
\text { coatings - Pretreatment of iron } \\
\text { or steel to reduce the risk of } \\
\text { hydrogen embrittlement(IDT } \\
\text { ISO 9587:1999) }\end{array}$ \\
\hline 15 & GB/T 19350-2012 & $\begin{array}{l}\text { Metallic and other inorganic } \\
\text { coatings - Post-coating } \\
\text { treatments of iron or steel to } \\
\text { reduce the risk of hydrogen } \\
\text { embrittlement(IDT } \\
9588: 2007)\end{array}$ \\
\hline 16 & GB/T 26107-2010 & $\begin{array}{l}\text { Metallic and other inorganic } \\
\text { coatings - Test for residual } \\
\text { embrittlement in both metallic- } \\
\text { coated and uncoated } \\
\text { externally-threaded articles } \\
\text { and rods - Inclined wedge } \\
\text { method(IDT ISO 10587:2000) }\end{array}$ \\
\hline 17 & GB/T 24185-2009 & $\begin{array}{l}\text { Test method for measurement } \\
\text { of hydrogen embrittlement } \\
\text { threshold in steel by the } \\
\text { incremental step loading } \\
\text { method }\end{array}$ \\
\hline 18 & $\begin{array}{l}\text { GB/T 3098.17- } \\
2000\end{array}$ & $\begin{array}{l}\text { Mechanical properties of } \\
\text { fasteners--Preloading test for } \\
\text { the detection of hydrogen } \\
\text { embrittlement--Parallel } \\
\text { bearing surface method(IDT: } \\
\text { ISO 15330:1999) }\end{array}$ \\
\hline 19 & $\begin{array}{l}\text { ANSI/NACE } \\
\text { TM0284-2016 }\end{array}$ & $\begin{array}{l}\text { Evaluation of pipeline and } \\
\text { pressure vessel steels for } \\
\text { resistance to hydrogen-Induced } \\
\text { cracking }\end{array}$ \\
\hline 20 & $\begin{array}{l}\text { EN ISO 2626: } \\
1995\end{array}$ & $\begin{array}{lll}\text { Copper } \quad- & \text { Hydrogen } \\
\text { embrittlement test } & \end{array}$ \\
\hline 21 & EN 2831: 1993 & $\begin{array}{l}\text { Aerospace Series - Hydrogen } \\
\text { Embrittlement of Steels - Test } \\
\text { by Slow Bending }\end{array}$ \\
\hline 22 & EN 2832: 1993 & $\begin{array}{l}\text { Aerospace Series - Hydrogen } \\
\text { Embrittlement of Steels - } \\
\text { Notched Specimen Test }\end{array}$ \\
\hline 23 & $\begin{array}{l}\text { EN ISO 7539-11: } \\
2014\end{array}$ & $\begin{array}{l}\text { Corrosion of metals and alloys } \\
\text { - Stress corrosion cracking - } \\
\text { Part 11: Guidelines for testing } \\
\text { the resistance of metals and } \\
\text { alloys to hydrogen } \\
\text { embrittlement and hydrogen- } \\
\text { assisted cracking }\end{array}$ \\
\hline 24 & EN 10229: 1998 & $\begin{array}{l}\text { Evaluation of Resistance of } \\
\text { Steel Products to Hydrogen } \\
\text { Induced Cracking (HIC) }\end{array}$ \\
\hline 25 & $\begin{array}{l}\text { EN ISO 11114-4: } \\
2017\end{array}$ & $\begin{array}{l}\text { Transportable gas cylinders - } \\
\text { Compatibility of cylinder and } \\
\text { valve materials with gas } \\
\text { contents - Part 4: Test methods } \\
\text { for selecting steels resistant to } \\
\text { hydrogen embrittlement }\end{array}$ \\
\hline 26 & $\begin{array}{l}\text { EN ISO 15330: } \\
1999\end{array}$ & $\begin{array}{l}\text { Fasteners - Preloading test for } \\
\text { the detection of hydrogen }\end{array}$ \\
\hline
\end{tabular}




\begin{tabular}{|l|l|l|}
\hline & & $\begin{array}{l}\text { embrittlement - Parallel } \\
\text { bearing surface method }\end{array}$ \\
\hline 27 & $\begin{array}{l}\text { EN ISO 17081: } \\
2014\end{array}$ & $\begin{array}{l}\text { Method of measurement of } \\
\text { hydrogen permeation and } \\
\text { determination of hydrogen } \\
\text { uptake and transport in metals } \\
\text { by an electrochemical } \\
\text { technique }\end{array}$ \\
\hline 28 & JIS B 1045:2001 & $\begin{array}{l}\text { Fasteners - Preloading test for } \\
\text { the detection of hydrogen } \\
\text { embrittlement - Parallel } \\
\text { bearing surface method }\end{array}$ \\
\hline 29 & JIS Z 3118:2007 & $\begin{array}{l}\text { Method for measurement of } \\
\text { amount of hydrogen evolved } \\
\text { from steel welds }\end{array}$ \\
\hline
\end{tabular}

\subsection{Distribution of standards for hydrogen storage and transportation}

As is shown in Figure 2, numbers of standards for hydrogen storage and transportation published by American organizations and SAC are both 20. Numbers of standards for hydrogen storage and transportation published by ISO, CEN and JISC are separately 13, 10 and 7. American standards, including CGA, NFPA, ASME, ANSI standards, cover general design and safety, receptacles, piping and pipelines, and hydrogen embrittlement. GB standards include general design and safety, receptacles, hydrogen embrittlement, but lacking of standards for hydrogen piping and pipelines. While, ISO, EN and JIS standards cover receptacles and hydrogen embrittlement.

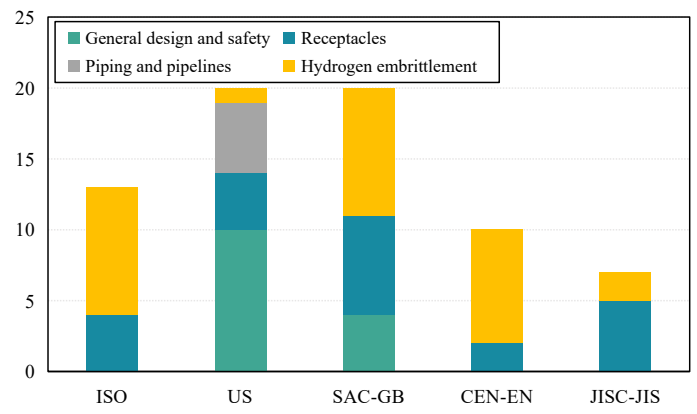

Fig. 2. Numbers of Standards for Hydrogen Storage and Transportation Published by Different Organizations and Countries

As is shown in Figure 3, numbers of standards for hydrogen embrittlement are more than that of the others, which accounts for about $40 \%$. Numbers of standards for general design and safety, receptacles, and piping and pipelines account for $20 \%, 32 \%$ and $7 \%$ separately. Standards for hydrogen piping and pipelines should be emphasized.

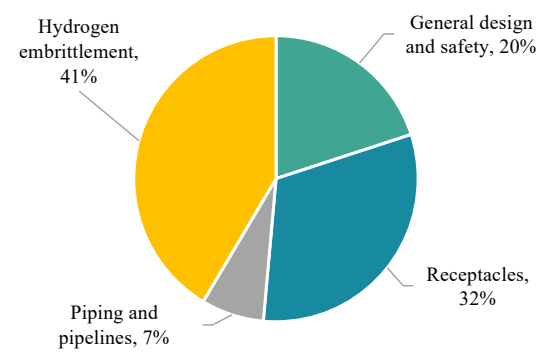

Fig. 3. Distribution of Standards for Hydrogen Storage and Transportation Based on Standard Types

\section{Conclusions}

Hydrogen storage and transportation are the intermediate link of hydrogen production and the point of end-use. Standards for hydrogen storage and transportation published by ISO, CGA, NFPA, ASME, ANSI, SAC, CEN and JISC cover general design and safety, receptacles, piping and pipelines, hydrogen embrittlement, etc. Numbers of standards for hydrogen embrittlement are more than the others. Standards for hydrogen piping and pipelines are only published by CGA and ASME. Chinese GB standards are mainly focused on general design and safety, gaseous hydrogen receptacles and hydrogen embrittlement. Standards for liquid hydrogen storage receptacles and safety, hydrogen piping and pipelines, and hydrogen transportation should be emphasized.

\section{References}

1. Hydrogen Council. Hydrogen scaling up - a sustainable pathway for the global energy transition (2017)

2. China Association of Automobile Manufactures, Report of fuel cell vehicle industry (2019)

3. International Organization for Standardization (ISO), https://www.iso.org

4. American National Standards Institute (ANSI), www.ansi.org

5. Compressed Gas Association (CGA), https://www.cganet.com

6. National Fire Protection Association (NFPA), https://www.nfpa.org

7. The American Society of Mechanical Engineers (ASME), https://www.asme.org

8. European Committee for Standardization (CEN), https://standards.cen.eu/

9. Standardization Administration of the P.R.C. (SAC), http://www.sac.gov.cn/sacen/

10. Japanese Industrial Standards Committee (JISC), https://www.jisc.go.jp/eng/index.html 